\title{
End users "Feedback" to improve ergonomic design of machinery
}

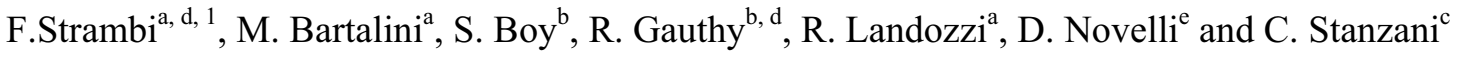 \\ ${ }^{a}$ Regione Toscana, A.USL 7 di Siena, UF. PISLL A.Val d'Elsa, Italy \\ ${ }^{b}$ ETUI, Brussels, Belgium \\ ${ }^{c}$ SindNova, Rome, Italy \\ ${ }^{d}$ EUR ERG, Center for Registration of European Ergonomist \\ ${ }^{e}$ Regione Toscana, Gruppo Macchine, ASF Firenze, Italy
}

\begin{abstract}
This paper describes the Feedback method designed to collect the contribution of users for the reconstruction and comprehension of the actual work and real activity for the improvement of the technical standards, design, manufacturing and use of machinery. The Feedback method has since now been applied successfully - in collaboration with public authorities, market surveillance bodies, social partners organization and technical institutes - to five different types of machines: woodworking machinery, forklift trucks, angle grinder and combine harvester. After ten years of experimentation in seven European countries Feedback has proved to be trans-nationally comparable and has attracted the interest of as much as 250 expert users - mostly workers, but also employers and technicians - who have shared their knowledge and experience by taking part in almost 30 working groups. The information collected with the Feedback method can be used by:

- CEN and ISO standardization committees and working groups to become aware of the problems relating to the real use of specific machines in different work contexts, and thus to be able to draw up new or to revise existing standards accordingly;

- Designers and manufacturers to produce better, more comfortable and safer machines and to provide precise instructions for use;

- Employers, users and workers for training purposes and for defining appropriate work procedures;

- Inspection bodies to enhance their knowledge and improve the efficiency of their interventions and advice.
\end{abstract}

Keywords: feedback method, machinery, ergonomics, end user, real work activity.

\section{Introduction}

Machinery designed and manufactured in conformity with the so-called harmonized standards - drawn up by CEN-CENELEC under a mandate from the European Commission - is presumed to comply with the essential requirements covered by those standards: armed with this presumption, the manufacturer can affix the CE mark and the machine will be allowed to move freely within the European market.

Unfortunately, serious machinery accidents continue to occur in workplaces, many involving machinery that complies with harmonized standards: persistent ergonomic, health and safety issues remain.

There is evidence that shortcomings in machinery currently on the European market are often due to design and manufacturing deficiencies and hence non-compliance with the Essential Safety Requirements (ESR) of the Machinery Directive.

Evident is a deficit of knowledge and information during the framing and/or periodic revision of harmonized standards, as a result of which issues around compliance with ergonomics principles and

1) Corresponding author. Email address: f.strambi@us17.toscana.it 
the health and safety of users of the machinery go unidentified and unresolved.

Information obtained from market surveillance, although invaluable, is not always sufficient - even when integrated in occupational accident data collection (EUROSTAT) - for timely identification of all the critical situations that can arise from the use of machinery by users in different operating contexts in the Member States.

This is made even more relevant by the extensive base of micro, small and medium-sized enterprises in all EU Member States whose modest human, financial and cognitive resources are stretched by the major difficulty of staying in the market and providing protection for their workers. It is in these small entities more than elsewhere that the intrinsic safety of machinery must be improved.

In any event, there is at present no system for addressing the health problems that the use of machinery may cause to users in terms of physical and psychological disorders and strains that may in time not only cause occupational diseases but also adversely affect well-being and productivity at the workplace.

Collecting users' experiences by reconstructing their activities, how they perform their work in different real-life operating conditions, will yield knowledge on the problems that emerge from common, everyday use and help identify possible corrections and improvements to harmonized technical standards and machinery design and manufacture.

Social partners can play a key role as vehicles of machinery users experience, and the European legislation acknowledges this. In fact, the EU's Machinery Directive [4], article 7.4, states that the social partners should be enabled "to have an influence at national level on the process of preparing and monitoring the harmonized standards".

In 1997 the European Trade Union Institute, ETUI, commissioned a study from Sind Nova-Roma and A.USL 7 of Siena, Italy, to develop a method for collecting the knowledge of workers who are expert users of machinery through reconstruction of their jobs using different machines in various micro, small and medium-sized enterprises in Europe. The method was to yield concrete results within a reasonable time using limited resources and validated, verifiable and updatable instruments.

The Feedback Method designed by Fabio Strambi [25] is derived directly from the method used to carry out an ergonomic analysis [18, 20, 23, 24, 26] of the organizational structure of work, to identify critical points, and to make suggestions and offer solutions, which was tried and tested in research, studies and safety campaigns financed by the European Coal and Steel Community in the 1980s. The results obtained from successive applications of the method have been published $[22,25]$ and were also presented to a seminar organized by the ETUI in Brussels in March 2006 [1] attended by representatives of the European Commission, where the concrete possibility of collecting users' experience as input to improve the standardization process was noted. The following paragraph included in the European Commission's (Directorate General for Enterprise and Industry) Mandate to CEN and CENELEC for standardization in the field of machinery is particularly salient [19] : “...\&3.5 When executing the standardisation tasks covered by this mandate, CEN and CENELEC are requested to take due account of feedback from endusers of the machinery concerned.".

The importance of involving users in the design of machinery is recognized in most standards that deal with ergonomic design principles. In fact, "Feedback from the use of the machinery is ..strongly recommended.." because it ".. helps to identify measures and improvements for future design. [5].

Often, standards provide for workers to be involved both in risk assessment [8, 15], and in the design phase [5], through the use of prototypes, mock-ups, models and/or laboratory simulations. In simulations, operator feedback can be obtained in various ways: group discussions, interviews, questionnaires, checklists, observational studies [5]. Although their value is in principle uncontested, the question remains as to whether simulations could capture the complex reality of working with machinery.

It is worth pointing out that simulations with machinery models and prototypes:

- Are often confined to pre-defined environments which cannot reflect the actual work environment with its multiple variables;

- Are time-limited, whereas problems from prolonged use of machinery may only arise over longer timeframes;

- Are limited to restricted circles of users that are not and cannot be considered as reliable and sufficiently heterogeneous samples of a population of real users;

- The very fact of using machinery in a laboratory inevitably conditions the ways it is used and the 
worker's responsiveness, thereby rendering his impressions of the machinery unreliable;

- Are unable to predict all the possible circumstances that may occur during actual real use in various productive, social and economic contexts.

In reality, only the skilled and experienced enduser, the operator at the workplace, is able to provide relevant feedback on real work with a machine.

ISO standards [15, 16, 17] also provide for feedback from the end users of machinery, and affirm the need to continue monitoring the effect of the system in order to safeguard against longer-term deterioration in the performance or health of the users. The overall evaluation is to be carried out when the process is stabilized.

Importance is given to evaluating the working conditions through observation at the workplace and the need to plan studies to that end with the involvement of workers in the actual environment of use. Interestingly, ISO Standard 6385, in paragraph 3.3 [15], notes the need to evaluate work systems, especially for ergonomic purposes, in time, and then to monitor the effects on the workers once put in use.

The most important harmonised machinery safety standard, EN ISO 12100 [17], in paragraph 5.2 lists among the requested information for risk assessment: "3) the experience of users of similar machines and, whenever practicable, an exchange of information with the potential users.". It also provides a schematic representation of the risk reduction process which includes a three-step iterative method. Each step concludes by asking whether the planned risk reduction is attained. As things stand, this question is answered in the design stage, whereas a more exhaustive and practical answer could be given by the collection of experiences from actual users of not only similar machines, as required in paragraph 5.2 of the standard, but of the same machines already in use.

This requires a structured and standardized method that can also be proposed to designers and used systematically to give a clear and unequivocal answer and add to their knowledge.

The Feedback method [22, 25] is appropriately designed to collect users' input in reply to the questions asked in the standard and in the CEN guide [2] for the drafting of safety standards: "Is there sufficient feedback on the use of the existing safety standard?".

Such information can prove useful for the periodic revision of the machinery construction standards as well as the data yielded by other sources: market surveillance activities carried out by national authorities, analyses of accidents, feedback from designers and manufacturers.

\section{Methods}

The Feedback method $[22,25]$, involves five main steps: choice of the machine and collection of documentation; identification of companies and workplace inspections; working groups with skilled users; written report of the WGs results and its validation; final technical report.

\section{Choice of the machine and collection of documentation (Machine dossier)}

The Feedback method is applied whenever stakeholders identify a machine and a corresponding harmonised standard, which merits closer examination and analysis. The first step of the method is to collect any available technical documentation on the machine under review, so as to be aware of the main safety features (i.e. normal and abnormal use, residual risks). In this preliminary phase safety experts/ergonomists assemble a "machine dossier", which in summary includes whenever available - information on: harmonised standards; safety guidelines; statistics on undesired events associated with the machine; safeguard actions against the standard; market surveillance information; information provided by manufacturer about the geographical diffusion of the machine and its different models and/or configurations; instructions.

\section{Identification of companies where the machine is daily used and workplace inspections}

After identifying the territory and the production sector where the method will be applied, safety experts/ergonomists select the companies/enterprises to be inspected and where skilled machine users will be recruited; trade unions and employers' associations help with this step. Inspections are carried out by using forms containing the following elements: general company data; description of working environment where the machine under investigation is used and the relevant working methods; characteristics of the machines used in the company; information on accidents (and near misses) 
which have occurred in the company and involved the studied machine; information about the training provided for workers assigned to operate the machine. This information will be used during the job ergonomic analysis, carried out in working groups, when skilled users will be guided by a facilitator in reconstructing their job based on machine activities carried out daily.

\section{Working groups and work analysis with skilled users of the machine}

Working groups (WG) are then formed, each group being made up of 5 to 9 users: besides workers, the group may include company engineers, craftsmen or employers with knowledge and experience in the use of the machine (these people should be the ones who use the machine in the normal course of production). It is essential that the participants come from different working situations, with at least three operators from different companies, in order to attenuate the inevitable specificities connected with a single company, and to provide a job reconstruction representative of the daily tasks across different working contexts. The working group activity, normally concentrated in a four hours meeting, is based on two preliminary steps. Firstly, the facilitators (safety experts/ergonomists) provide the users with basic documentation (the relevant technical standards, the description of the most important residual risks indicated by the manufacturers in the instructions, a description of the dynamics of the most serious accidents, etc.). Secondly, each working phase is split into elementary operational tasks, on the basis of the information collected during the company inspections: from the set-up of the machine up to the maintenance and cleaning operations when the work is ended. Thereafter the facilitators introduce the job ergonomic analysis through which the group will reconstruct in detail the daily work activities and then start a systematic analysis of each work activity/phase with the help of the Feedback working group sheet, Table 1.

For each activity/work phase, the job tasks are identified, and for each of them the following elements are put in writing: operating procedure, competence, hazards/risks and suggestions, Table 1.

It is important to note that the facilitators leading the discussion allow the workers to act as key players in evaluating their own working environment. The facilitators' role consists in supplying information, speeding up the participants' contribution to the reconstruction of the activity and the job, and guiding the users' evaluations of the safety issues and possible preventive action.

\section{Written report of the $W G$ results and its validation}

At the end of the process, the facilitator transfers the results onto a "legible copy" of the Feedback sheet and deliver it to every participant for their validation and/or for any corrections/additions. This step is essential, not least so that the more reticent members have an opportunity to contribute their opinions and suggestions.

\section{Project overview and final technical report}

The final phase of the Feedback Method consists in the drafting of the project overview and the final technical report. The project overview describes all the different project phases and outcomes, from the assembling of the machine dossier to the consolidation and validation of the $\mathrm{WG}$ report.

Table 1

Feedback working groups sheet

\begin{tabular}{|c|c|c|c|c|}
\hline \multicolumn{5}{|c|}{ 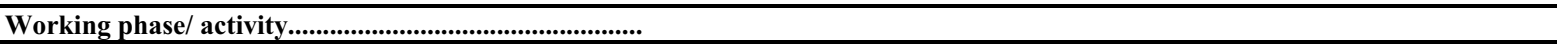 } \\
\hline Sequence & Operating Procedure & Competence & Hazards/Risk/Critical aspects & Suggestions for prevention \\
\hline & $\begin{array}{l}\text { Description of the } \\
\text { procedure for carrying } \\
\text { out the tasks listed with } \\
\text { information on the } \\
\text { equipment used, safety } \\
\text { devices and personal } \\
\text { protective equipment, } \\
\text { PPE, people involved. }\end{array}$ & $\begin{array}{l}\text { Information about the } \\
\text { competence required for } \\
\text { optimum execution of task } \\
\text { (technical skill/ knowledge, } \\
\text { use of equipment, materials, } \\
\text { procedures ... and } \\
\text { information about the } \\
\text { instruction handbook). }\end{array}$ & $\begin{array}{l}\text { Factors that represent a } \\
\text { hazard/risk as regards the } \\
\text { machinery itself, equipment, } \\
\text { safety devices, surrounding } \\
\text { conditions (e.g. microclimate, } \\
\text { dust, lighting or layout), fatigue } \\
\text { and organisation (frequency, } \\
\text { shifts etc.). }\end{array}$ & $\begin{array}{l}\text { Improvement of the standard, } \\
\text { design and manufacturing of the } \\
\text { machinery. Suggestions on how } \\
\text { to eliminate the hazards and to } \\
\text { prevent the risks identified; } \\
\text { information on training, } \\
\text { instruction handbook, safety } \\
\text { devices, procedure, PPE; need of } \\
\text { further researches. }\end{array}$ \\
\hline
\end{tabular}


Afterwards the facilitator drafts a synthesis of the WG report, in order to facilitate the transition from words to deeds.

This final technical report is structured in such a way that its content is addressed to:

- Standard setters to become aware of the problems relating to the real use of specific machines in different work contexts and thus to draw up new or to revise existing standards accordingly;

- Designers and manufacturers to produce better, more comfortable and safer machines and to provide precise instructions for use;

- Employers, users and workers for training purposes and for defining appropriate work procedures;

- Inspection bodies to enhance their knowledge and improve the efficiency of their interventions and advice.

This final technical report therefore becomes the centrepiece of the job carried out and constitutes a technical synthesis of the contributions made by users both during the inspections and within the working group debates.

\section{Results}

The Feedback method has since now been applied successfully to five different types of machines, Table 2, marked "CE" and manufactured in conformity with their " $\mathrm{C}$ " standards, in collaboration with public authorities, market surveillance bodies, social partners organization and technical institutes, Table 3 .

Examples of activity description with TeleHandlers are reported in Table 4, Manchester WG, and in Table 5, Florence WG. The working groups have provided many suggestions for the improvement of standards and also precious informations for designers, manufacturers and even for the buyers/users of machinery. The main indications to improve the standards of self-propelled machinery forklift, combine harvesters and telehandlers have focused on important safety issues such as stability and visibility. The risk of overturning is high in soft ground or slopes. The forklift overturns just steering at speed.

Table 2

Machines studied by the means of the Feedback method

\begin{tabular}{|c|c|c|c|c|c|c|c|}
\hline Type of machine & C standard & Countries & Factories & Users & $\begin{array}{l}\text { Feedback } \\
\text { working groups }\end{array}$ & Machines & Period \\
\hline $\begin{array}{l}\text { Woodworking } \\
\text { Machines }\end{array}$ & $\begin{array}{l}\text { EN 1870-1:1999; } \\
\text { EN 848-1:1998 }\end{array}$ & I & 14 & 28 & 4 & 58 & 1997-2001 \\
\hline Forklift Trucks & EN 1726-1:1998 & I, UK, FIN, F, D & 45 & 60 & 11 & 1658 & 2003-2004 \\
\hline Angle Grinders & EN $50144-1: 1999$ & I & 19 & 19 & 3 & 85 & 2005 \\
\hline Telehandlers & EN 1459-1:1998 & I, UK, FIN, S, D & 35 & 35 & 5 & 39 & 2006-2008 \\
\hline Combine Harvesters & EN ISO 4254-7:2009 & $\mathrm{I}, \mathrm{UK}, \mathrm{DK}, \mathrm{D}$ & 46 & 110 & 6 & 117 & 2009-today \\
\hline
\end{tabular}

Table 3

Partners of the Feedback method studies (1997-2011)

\begin{tabular}{|ll|}
\hline Public authorities, administrations, market surveillance bodies & Social partners organization and technical institutes \\
\hline HSE, Health and Safety Executive, United Kingdom & ETUI, European Trade Union Institute, Belgium \\
GroLa BG, Großhandels- Berufsgenossenschaft, Deutschland & EFFAT, European Federation Food Agriculture and Tourism, Belgium \\
KAN, Kommission Arbeisshutsz und Nurmung, Deutschland & ACIMALL, Association Wood Working Machinery Manufacturers, Italy \\
Ministère de l'emploi, de la République Française, France & EPSU, European Federation of Public Service Unions, Belgium \\
Ministry of Social Affairs and Health of Finland, Finland & Fagligt Faelles Forbund, United Federation of Danish Workers, Denmark \\
A. USL, Local Health Unit Enterprise,: 1 Massa e Carrara; 3 Pistoia; & LO, Landsorganisationen i Sverige, Sweden \\
4 Prato; 10 Firenze; 7 Siena, Italy & $\begin{array}{l}\text { SEKO, Union for Service and Communications Employees, Sweden } \\
\text { Regione Toscana, Italy }\end{array}$ \\
ISPESL/INAIL, National Work Accident Insurance Institute, Italy & Unite the Union, Britain and Ireland Union, United Kingdom and Ireland \\
\hline
\end{tabular}


Table 4

Telehandlers working groups, Manchester, United Kingdom. Work activity: moving the truck

\begin{tabular}{|lllll|}
\hline $\begin{array}{l}\text { Sequence } \\
\text { of tasks }\end{array}$ & $\begin{array}{l}\text { Operating } \\
\text { procedure }\end{array}$ & Competence & Hazards/risks/critical aspects & Suggestions for prevention \\
\hline $\begin{array}{l}\text { Moving } \\
\text { the truck }\end{array}$ & $\begin{array}{l}\text { Moving } \\
\text { forward }\end{array}$ & $\begin{array}{l}\text { Drivers aware } \\
\text { that boom must } \\
\text { be as low as } \\
\text { possible during } \\
\text { driving to } \\
\text { maximize } \\
\text { visibility on the } \\
\text { right hand side }\end{array}$ & $\begin{array}{l}\text { Risk of collisions } \\
\text { Not always possible to drive } \\
\text { with boom low, e.g. on very } \\
\text { rough ground, or when } \\
\text { carrying suspended or wide } \\
\text { loads } \\
\text { Can be dazzled by sunlight }\end{array}$ & $\begin{array}{l}\text { Operators would like a visibility aid for the off-side that works } \\
\text { boom is set lower, giving driver a better chance of seeing over it. } \\
\text { for all boom angles. For example, it was suggested to have a } \\
\text { boom mirror whose angle adjusts as the boom is raised or } \\
\text { lowered } \\
\end{array}$ \\
& & & $\begin{array}{l}\text { Fit fish eye mirror on front off side } \\
\text { Fit tinted plastic strips to window for sun visors. Another } \\
\text { suggestion was to fit a roller blind }\end{array}$ \\
\hline
\end{tabular}

Table 5

Telehandlers working groups, Florence, Italy. Work activity: preliminary operations

\begin{tabular}{|c|c|c|c|c|}
\hline $\begin{array}{l}\text { Sequence of } \\
\text { tasks }\end{array}$ & Operating procedure & Competence & $\begin{array}{l}\text { Hazards/risks } \\
\text { critical aspects }\end{array}$ & Suggestions for prevention \\
\hline \multirow[t]{3}{*}{$\begin{array}{l}\text { Sitting in } \\
\text { the drivers' } \\
\text { cab }\end{array}$} & $\begin{array}{l}\text { The operator, once seated, adjusts } \\
\text { the height and depth of the seat. In } \\
\text { some models, it is also possible to } \\
\text { adjust the suspension to the } \\
\text { operator's weight }\end{array}$ & $\begin{array}{l}\text { Knowledge of the } \\
\text { position of the seat- } \\
\text { adjusting controls }\end{array}$ & $\begin{array}{l}\text { If the seat is not adjusted, } \\
\text { the driver's position may } \\
\text { not be ergonomic and } \\
\text { may increase the } \\
\text { exposure to vibrations }\end{array}$ & $\begin{array}{l}\text { Requirement for the manufacturer to } \\
\text { report the exposure to vibrations under } \\
\text { normal conditions of use (relative to the } \\
\text { type of terrain on which the vehicle can } \\
\text { operate) }\end{array}$ \\
\hline & $\begin{array}{l}\text { Adjustment of the rear-view } \\
\text { mirrors }\end{array}$ & $\begin{array}{l}\text { The adjustment is } \\
\text { carried out manually } \\
\text { and help from a } \\
\text { colleague is needed to } \\
\text { adjust some mirrors } \\
\text { that are far from the } \\
\text { cab }\end{array}$ & $\begin{array}{l}\text { Even with well-placed } \\
\text { rear view mirrors, blind } \\
\text { angles remain, thereby } \\
\text { increasing the risk of } \\
\text { collisions and accidents }\end{array}$ & $\begin{array}{l}\text { Install rear-view mirrors that can be } \\
\text { adjusted from the driver's cab to provide } \\
\text { full visibility around the vehicle }\end{array}$ \\
\hline & $\begin{array}{l}\text { Use of holding systems on the } \\
\text { driver's seat } \\
\text { - safety belt buckled at the waist } \\
\text { (users have reported the need to } \\
\text { get up and get out of the vehicle } \\
\text { very frequently during normal } \\
\text { work. This is not conducive to the } \\
\text { use of safety belts) }\end{array}$ & $\begin{array}{l}\text { Knowledge of how to } \\
\text { use the belt and } \\
\text { awareness of the need } \\
\text { to use it when the } \\
\text { vehicle is moving }\end{array}$ & $\begin{array}{l}\text { Risk of more serious } \\
\text { accidents in case of } \\
\text { collision and overturning }\end{array}$ & $\begin{array}{l}\text { Because the safety belt buckled at the } \\
\text { waist gives workers the impression that } \\
\text { they are not properly seated in the driver's } \\
\text { cab, it has been proposed to use belts } \\
\text { buckled on the chest. Or, as an } \\
\text { alternative, to adopt other systems for } \\
\text { securing the driver. However, such } \\
\text { systems must be easy to use }\end{array}$ \\
\hline
\end{tabular}

Controls are needed on the speed based on the variation of the inclination/height of the arm and the loading unit, fixing maximum limits that exclude the risk of overturning under the conditions foreseen by the manufacturer.

Indicators must be made compulsory for inclination (lateral and longitudinal, on both axes of the vehicle), on the load in the forks, on the pressure in the tyres, etc.

Adoption of alarm signals to warn that the vehicle and the load are in danger of overturning or of losing stability.

The telehandlers WGs indicate problems linked to the safety belts design, Table 5; the combine harvester WGs instead denounce that the safety belts are compulsory only for the machine equipped with roll over protection structure, ROPS.

In relation to the self-propelled machines it is necessary to define specific standardized methods for evaluating the visibility from the driver's cab, Table $4 ; 5$, and the introduction of auxiliary systems to ensure sufficient visibility around the vehicle as and when needed; these machines need also an adequate, standardised design of the position and functions of the controls.

The reports of all the machines WGs indicate problems concerning usability of the protection devices, especially when using woodworking machinery and angle grinder. 
In particular for the angle grinders standards have to specify the characteristics of the mains switch on/off in order to avoid a unwanted operation, inadvertent starting by also excluding the possibility to lock the device in the ON position.

The reports of the woodworking machines' WGs evidence the need to remove all the wood dust, a classified carcinogenic agent [3], both during the production activity and cleaning and maintenance phase. According to those reports, standards should require each machine to be equipped with an extraction system of the dust together with an interdiction to use compressed air to clean the machine.

Further important recommendations related to the maintenance of machinery are:

- Forklifts: to provide an automatic filling system for the traction battery pack;

- Telehandlers and combine harvesters: to improve the automatic cleaning devices for glazed surfaces and mirrors; to provide the possibility to visually check the tire pressure; to include in standards a statement by the manufacturer about the level of noise and vibrations produced by the machine in the same condition of the intended use, in the cockpit and not just outside the self-propelled machinery;

- Combine harvesters: to install adequate permanent means of access to machinery; to provide machines with automatic greasing systems and/or remote greasers.

Regarding self propelled machines and particularly the forklifts, the design of the pedals controlling forward/reverse and stop should be unified according with the one provided in automobiles.

In the examined sample of forklifts, different dispositions were found even inside the same company. Both designers and manufacturers should better address the residual risks management and improve the contents and the quality of the use and maintenance handbook (instruction manual); for example describing the correct work procedure, the worker training need, the environment requirements, the personal protective equipment and so on. A clear recommendation provided by the working groups analysing woodworking machines is the need to complete the existing instruction with information on the exact use of guides and fences, on the safe handling and fitting of the tools and on how to perform special activities. The angle grinder working groups suggested to write in the handbook detailed instruction on how to minimize the risk associated with the electrical supply and accessories use.

\section{Conclusion}

The first relevant conclusion that can be drawn from this study is the high repeatability of the results obtained in many different production contexts in seven different European member states from applying the Feedback method to five CE-marked machines manufactured in conformity with their specific $\mathrm{C}$ standard, Table 2.

A detailed ergonomic analysis of the work with each machine done by more than one working group yielded a large body of valuable information on the specific characteristics of machine use in different work contexts and socio-cultural, climatic and microclimatic environments. The workers and companies involved gave the studies their active cooperation both for carrying out workface inspections and making skilled users available to workgroups.

In the Feedback method, the reconstruction and knowledge of actual work and real activity are not obtained from simple interviews, opinions and questionnaires, ethnographic observations or traditional focus group discussions but through a detailed ergonomic analysis following a specific procedure with the participation of skilled end users working in different companies. The best results are obtained when the same machine and work activity are analysed by more than one working group, possibly in different geographical areas and socioeconomic contexts.

The description of work activities, omissions or issues identified are of high intrinsic value for depicting what actually happens in daily real work in different workplaces as described by a group of those most immediately concerned - skilled machine users.

It is important to note that activity descriptions are not those of one individual skilled worker or even the aggregate of many individual skilled workers but the product of a Feedback working group of skilled workers interacting with one another and coordinated by a facilitator to draw up common background.

It is quite possible that the work activity may be done differently in other companies or other production contexts, and the Feedback working group's description may need to be revised to incorporate this diversity. This is not a disadvantage, but rather a major benefit of the Feedback method, 
which enables every user to compare the knowledge acquired against their specific reality and so to update and expand the content in a way adapted to the specific working environment, be it Italy, Brazil or the USA.

Using a standardized method that makes little demand on time and resources, multiple Feedback working groups can easily be set up to collect skilled users' experience with a specific machine and use this valuable information to a) identify failings in the standard or the design rather than in its use, b) to validate the results already obtained and c) to monitor improvements in the work activity and the efficacy of the ergonomic solutions applied. The outcomes of the Feedback method can also be validly used for evaluating and/or designing new machinery similar to the one under study: this is the case when dealing with the roll-over risk of any self-propelled machinery with a driver on board during use on uneven ground or gravel. The method can be used by workers' representatives or, more generally, representatives of consumers and users, to collect evidence for making improvements to various types of machinery, for example after the occurrence of unwanted events during the use of a machine so as to identify the causes and possible solutions.

The recommendations can then be forwarded to the appropriate CEN-CENELEC technical bodies. Key to the method's effectiveness, however, is the human factor and above all the full cooperation of expert users and technicians/ergonomists. The full participation and support of employees, employers, users and buyers of machinery, technicians and market surveillance personnel in putting the Feedback method into practice have been key to its successful application.

\section{References}

[1] S.Boy "A European system to improve machinery safety by drawing on users' experience". ETUI; Brussels, 2006.

[2] CEN Guide 414 "Safety of machinery - Rules for the drafting and presentation of safety standards", 2004.

[3] Directive 1999/38/EC of the Council amending for the second time Directive 90/394/EEC of the protection of workers from the risks related to exposure to carginogens at work and extending it to mutagens, 1999.

[4] Directive 2006/42/EC of the European Parliament and of the Council on machinery, 17 May 2006.

[5] EN 614-1:2006+A1:2009 "Safety of machinery Ergonomic design principles - Part 1: Terminology and general principles".
[6] EN 614-2:2000+A1:2008 "Safety of machinery Ergonomic design principles - Part 2: Interactions between the design of machinery and work tasks".

[7] EN 848-1:2007+A1:2009 "Safety of woodworking machines - One side moulding machines with rotating tool Part 1: Single spindle vertical moulding machines".

[8] EN 1005-2:2003+A1:2008 "Safety of machinery - Human physical performance - Part 2: Manual handling of machinery and component parts of machinery".

[9] EN 1459:1998+A2:2010 "Safety of industrial trucks - Selfpropelled variable reach trucks".

[10] EN 1726-1:1998+A1:2003 "Self-propelled trucks up to and including $10000 \mathrm{~kg}$ capacity - Part 1:General requirements".

[11] EN 1870-1:2007+A1:2009 "Safety of woodworking machines - Circular sawing machines - Part 1: Circular saw benches (with and without sliding table), dimension saws and building site saws".

[12] EN 13861:2002 "Safety of machinery. Guidance for the application of ergonomics standards in the design of machinery".

[13] EN 50144-2-3:2002 "Safety of hand-held electric motor operated tools - Part 2-3: Particular requirements for grinders, disk type sanders and polishers".

[14] EN ISO 4254-7:2009 “Agricultural machinery - Safety Part 7: Combine harvesters, forage harvesters and cotton harvesters".

[15] EN ISO 6385:2004 "Ergonomic principles in the design of work systems".

[16] EN ISO 9241-210:2010 "Ergonomics of human-system interaction. Part 210: Human-centered design processes for interactive systems".

[17] EN ISO 12100:2010 "Safety of machinery - General principles for design - Risk assessment and risk reduction".

[18] B.Maggi, A.Grieco "Il metodo delle congruenze organizzative per lo studio dei rapporti tra lavoro organizzato e salute. Un esempio di applicazione nel settore metallurgico" - Atti del Convegno "Aspetti emergenti dei rischi della metalmeccanica leggera”, pag. 161. Poggibonsi, Italia, 1986.

[19] Mandate to CEN and CENELEC for standardisation in the field of machinery. M/396 EN. Brussels, 19 December 2006.

[20] W.Morris, J.Wilson, T.Koukoulaki: "Developing a participatory approach to the design of work equipment. Assimilating lessons from workers esperience". ETUIREHS, ISBN 2-930003-50-2, 2004.

[21] J.A.Ringelberg, P.Voskamp "Integrating Ergonomic principles into $\mathrm{C}$ standards for machinery design. TUTB proposals for guidelines". ETUI, June 1996.

[22] F.Strambi, M.Bartalini, R.Cianotti, M.N.Tini, C.Stanzani "Feedback: a method to collect the contribution of machinery users in order to improve the quality of design standards". Proceedings ISSA. Nice, 2006.

[23] F.Strambi, G.Battista, A.Franzinelli "Salute e lavoro nel settore estrattivo: esperienze di formazione alla sicurezza" Atti del convegno "Materiali lapidei, tematiche di prevenzione e produzione", pag. 257. Morbegno, Maggio 1987.

[24] F.Strambi "Ergonomia e sicurezza in miniera: il contributo dell'azione comunitaria europea" - Atti del Convegno Nazionale "Lavoro e salute in miniera ed in cava". Massa Marittima (GR), 5 e 6 Dicembre 1991. 
[25] F.Strambi, C.Stanzani, M.Bartalini, M.Cucini "Ergonomia e norme tecniche di sicurezza: il contributo degli utilizzatori”. Editore Franco Angeli. Milano, 2001

[26] F.Strambi, F.Valentini, G.Battista "Esperienze di formazione alla sicurezza nel settore lapideo" - Atti del Congresso Internazionale "Sviluppo produttivo e rispetto delle risorse umane nell'estrazione e lavorazione dei materiali lapidei”, pag. 228. Siena, 14 Novembre 1986. 